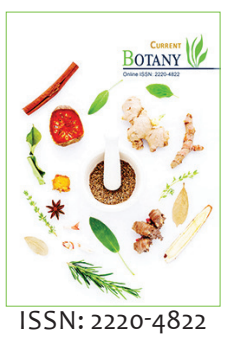

Received: February 19, 2020 Revised: April 14, 2020

Accepted: May 01, 2020 Published: May 12, 2020

*Corresponding Author: Sanoop Surendran Email: sanoopmoozhoor@ gmail.com

\section{Evaluation of genetic variability between yellow vein mosaic disease resistant gamma-irradiated okra mutant and parent}

\author{
Sanoop Surendran ${ }^{1 *}$, Punnakkal Sreedharan Udayan² \\ 'Research and Development Centre, Bharathiar University, Coimbatore, Tamil Nadu- 641 046, India, ${ }^{2}$ P.G. Department \\ of Botany \& Research Centre, Sree Krishna College, Guruvayur, Ariyannur P.O. Thrissur District, Kerala - 680 102, India
}

\begin{abstract}
Okra (Abelmoschus esculentus (L.) Moench is a member of the Malvaceae family. It has been cultivated as one of the most important fruit vegetables in various tropical countries. In okra, the Yellow Vein Mosaic Disease (YVMD) is caused by more than ten different viruses and the widespread incidence of disease transmitted by the vector Bemisia tabaci (Genn.) has highly affected the successful cultivation and production of the crop. Mutation breeding using radiations is one of the promising methods to get disease resistant elite cultivars of various crops. In this study, attempts were made to evaluate the genetic variability of gamma-ray irradiated mutant of okra. Four ISSR primers generated 26 amplified fragments. Of the 26 fragments, the lowest number of fragments (5) was produced by the primer ISSR12. Between the parent (P) and mutant $\left(\mathrm{M}_{4}\right.$; mutant from fourth-generation) varieties of okra, primer ISSR07, primer ISSR16 and primer ISSR21 produced two monomorphic bands and three polymorphic bands (60\% polymorphism) whereas primer ISSR12 produced one monomorphic band and three polymorphic bands (75\% polymorphism). The mean percentage of polymorphism generated by four primers was $63.75 \%$. Although the level of polymorphism exhibited by different primers varied from intermediate (60\%) to high (75\%), all primers could distinguish parent and gamma-irradiated mutant varieties of okra.
\end{abstract}

KEYWORDS: Genetic variability, ISSR markers, Abelmoschus esculentus, Yellow Vein Mosaic Virus.

\section{INTRODUCTION}

Okra (Abelmoschus esculentus (L.) Moench, popularly known as lady's finger, is a member of Malvaceae family. Okra is of African origin and now, it has been cultivated in various tropical countries including India $[1,2]$. The slightly curved fruit of Okra is a greenish capsule having six chambered pod $[2,3]$. It grows upto $20 \mathrm{~cm}$ and contains numerous seeds [2]. The seeds are a rich source of protein owing to the high levels of lysine content $[2,4]$. Globally, India ranks first in the annual production of okra and it covers upto $70 \%$ of the total income generated by the export of fresh vegetables, excluding onion [5].

Consistency in maintaining annual productivity of okra is fluctuating due to various factors such as inefficacy of fertilizers, improper irrigation and infestation caused by different pathogens [6]. Among the various pathogens, the disease caused by Yellow Vein Mosaic viruses is common which is characterized by yellowing of leaves, low yield of fruits coupled with stunted growth [7]. The vector which transmits the disease is whitefly Bemisia tabaci (Genn.) [8]. Although, using transgenic methods, many YVMV resistant okra varieties have been developed, tested and released, no variety could retain the resistance for long [8]. In plant breeding, mutation breeding using radiations is a promising method as radiations can induce genetic variability within a short time [9] and such induced mutations were reported to be effective in the development of elite cultivars of cereals, fruits and other crops [10]. Through gamma ray induced mutation, crop diversity and productivity were improved significantly all over the World [11]. Gamma radiation was employed for developing almost $64 \%$ of all mutant varieties released until the beginning of $21^{\text {st }}$ century [12] Various vegetative and reproductive parameters were reported to be enhanced when mutant okra varieties were developed using gamma irradiation [13]. Recently in okra, various studies reported with induced mutagenesis by using different doses of gamma rays $[14,15,16,17,18]$.

Copyright: $\odot$ The authors. This article is open access and licensed under the terms of the Creative Commons Attribution License (http://creativecommons.org/licenses/by/4.0/) which permits unrestricted, use, distribution and reproduction in any medium, or format for any purpose, even commercially provided the work is properly cited. Attribution - You must give appropriate credit, provide a link to the license, and indicate if changes were made. 
For the improvement of plant breeding approaches, the knowledge of genetic diversity and construction of linkage maps would be essential [19] and hence, DNA markers are employed to characterize genotypes [20]. Genetic variability within and among species has been studied extensively using various DNA markers such Random Amplified Polymorphic DNA (RAPD), Simple Sequence Repeats (SSR), Amplified Fragment Length Polymorphism (AFLP) and Inter-Simple Sequence Repeats (ISSR) [21,22,23,24,25]. In genetic variability analyses, microsatellites exhibit a high degree of variability [26]. Since the isolation of microsatellites are laborious, time-consuming and expensive, ISSR markers are often used to evaluate genetic diversity among closely related species as ISSR-PCR targets regions that are lying within the range of microsatellites [27]. ISSR regions lying within the range of microsatellite repeats are highly effective in revealing inter and intra-specific polymorphisms [28]. ISSR marker is effective in evaluating genetic variability of individuals with close relationship $[29,30]$ and the major advantages in using ISSR markers to study genetic diversity are i) longer primers, ii) more polymorphic fragments and iii) primer designing does not require knowledge of genome sequence [31,32].

The present work is a continuation of a previous study which confirmed relatively high yield and disease resistant characteristics of gamma irradiated mutants of okra when compared to parent [13]. In view of the high yield and disease resistance obtained from okra mutant, genetic variability between parent and gamma irradiated mutant of okra was evaluated as the knowledge of genetic variation would facilitate the selection of mutant to be involved in cross breeding.

\section{MATERIALS AND METHODS}

In our previous study, out of the 40 accessions of Abelmoschus esculentus (L.) Moench collected from different localities of Kerala, a superior variety namely 'Anakomban' was selected for induced mutagenesis. The seeds of selected variety were irradiated at seven different dose levels of gamma radiation including control. The seeds containing optimum moisture content were carefully bagged in plastic covers and exposed to the gamma ray doses such as 100Gy, 150Gy, 200Gy, 300Gy, 400Gy and 500Gy. These doses were delivered from a 3500 curie $\mathrm{CO}^{60}$ gamma cell installed at Kerala Agricultural University, Vellanikkara, thrissur District, Kerala, India. The gamma source was stationery and its irradiations were done at a dose rate of 3200 Rads/min by moving down a cylindrical gasket carrying the seeds.

In order to study the detailed morphological and yield attributing characters, the field experiments were conducted in the Botanical Garden of Sree Krishna College, Guruvayur, Kerala, India. The experiment was laid out in Randomised Block Design, with seven treatments and four replications. The 140 seeds of each of the seven treatments were sown on the third day of treatment at the rate of 20 progeny rows/treatment with proper randomization. The seeds were soaked overnight to facilitate uniform pre- soaking. Data on morphological and yield attributing characters were gathered from $M_{1}, M_{2}, M_{3}$ and $M_{4}$ generations. The plants obtained from seeds which are treated with 400Gy has the highest values for mean height, number of leaves, number of fruits/plant, fruit characteristics such as length, girth, weight, number of seeds/ fruit and weight of 100 seeds. After evaluation of four generations, identified a superior one based on their yield, yield attributing characters and disease rating of Yellow Vein Mosaic disease. The intensity of disease scoring of Yellow Vein Mosaic disease was evaluated in this in-vivo experiment by using the disease rating scale [33]. The scoring was done according to the characteristic symptoms appeared on the leaves or fruits of each plant.

In the present study, for evaluating the genetic variability, leaves were collected from selected mutant of 400Gy gamma rays treated plants in $\mathrm{M}_{4}$ generation (Mutant) and non-treated plant (Parent) cultivated in the Botanical Garden of Sree Krishna College, Guruvayur, Kerala, India. Collected samples were stored in separate bags at $-80^{\circ} \mathrm{C}$ for further processing.

Modified Cetyl Trimethyl Ammonium Bromide method (CTAB) was used for extraction of total genomic DNA from treated and non-treated okra samples. One and half gram of samples was powdered separately in liquid nitrogen using mortar and pestle. The powdered samples were extracted in $15 \mathrm{~mL}$ CTAB buffer (2\% CTAB, $100 \mathrm{mM}$ TrisHCl, 20mM EDTA, 1.5 $\mathrm{M} \mathrm{NaCl}, 2 \%$ PVP and $0.2 \% \beta$-mercaptoethanol) containing $0.1 \mathrm{mg} / \mathrm{mL}$ proteinase $\mathrm{K}$. The mixture was then incubated for 15 minutes at $55^{\circ} \mathrm{C}$ in water bath. The incubation was followed by centrifugation of the mixture at $12000 \mathrm{rpm}$ for 15 minutes to spin the cell debris. Equal volume of chloroform: isoamyl alcohol (24:1) was added to the supernatant. The mixture was then centrifuged at $12000 \mathrm{rpm}$ for 15 minutes. The DNA was precipitated by adding 0.7 volume of isopropanol to the aqueous phase centrifuged at $12000 \mathrm{rpm}$ for 15 minutes. The DNA pellet obtained was washed with $70 \%$ ethanol. Ethanol was completely evaporated by air drying. The DNA pellet was re-suspended in $500 \mu \mathrm{L}$ of TE buffer (10 mM Tris (pH 8.0) and lmM EDTA).

The total genomic DNA was purified using HiMedia columns (HiMedia, Mumbai) as per manufactures instruction. The purified DNA samples were analyzed on $1.0 \%$ agarose gel using $0.5 \mathrm{X}$ TBE buffer and were quantified using spectrophotometer. The PCR amplifications were performed in volumes of $25 \mu \mathrm{l}$ volume containing $50 \mathrm{ng}$ of DNA, 1.25 units Taq DNA polymerase, $0.1 \mathrm{mM}$ dNTPs and $2.5 \mathrm{mM} \mathrm{MgCl}_{2}$. The list of ISSR primers used in the study is listed in Table 1.

The following conditions were used for all primers: initial denaturation at $94^{\circ} \mathrm{C}$ for 2 minutes, followed by 40 cycles of $94^{\circ} \mathrm{C}$ (denaturation) for 30 seconds, $45^{\circ} \mathrm{C}$ (annealing) for 45 seconds and $72^{\circ} \mathrm{C}$ (extension) for 2 minutes and the final extension at $72^{\circ} \mathrm{C}$ for 15 minutes. The PCR products were loaded on $1.5 \%$ agarose gel and documentation of the amplification products was done using the Biorad (Bioimaging

Table 1: List of ISSR primers used in the study

\begin{tabular}{|c|c|c|c|c|}
\hline No. & Primers & Sequence & Size (bp) & $\mathrm{Tm}={ }^{\circ} \mathrm{C}$ \\
\hline 1 & ISSR07 & CACACACACAGC & $1375-200$ & 45 \\
\hline 2 & ISSRI2 & CACCACCACGC & $3530-200$ & 45 \\
\hline 3 & ISSRI6 & GAGAGAGAGAGAGAGAGAT & 2027-831 & 48 \\
\hline 4 & ISSR21 & GATAGATAGATAGATA & $1584-1375$ & 40 \\
\hline
\end{tabular}


System) and analysis of bands was done using the analysis software (PyElph 1.4). For the analysis, clear, unambiguous and reproducible bands were selected. The presence of bands was scored as ' l'; while the absence of bands or very faint bands were scored as ' 0 '. The level of polymorphism generated by each primer was estimated as the proportion of polymorphic loci to the total number of loci scored. A neighbor-joining dendrogram was developed through an unweighted pair group method with arithmetic mean (UPGMA) using PyElph 1.4 module.

\section{RESULTS AND DISCUSSION}

Among the 12 ISSR primers used in the study, four primers (ISSR07, ISSR12, ISSR16, and ISSR21) produced clear and reproducible bands showed in Table 2 and Figure 1. Four primers produced 26 reliable fragments and scored in seven loci. Each primer generated

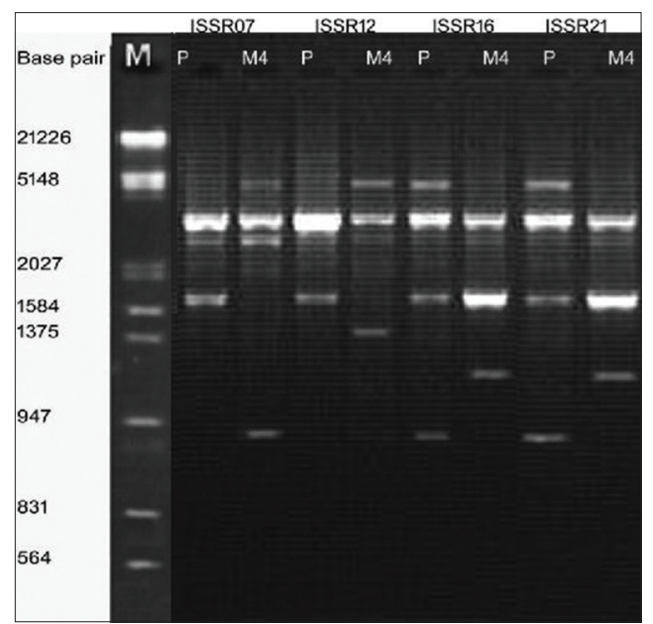

Figure 1: PCR amplification profile of ISSR markers an average of 6.5 bands. The lowest number of fragments (5) was produced by the primer ISSR12. Among the 26 fragments, 12 were found to be polymorphic $(46.15 \%)$. Between the parent $(\mathrm{P})$ and mutant $\left(\mathrm{M}_{4}\right.$; mutant of fourth-generation), primer ISSR07, primer ISSR16 and primer ISSR2 1 produced two monomorphic bands and three polymorphic bands (60\% polymorphism), whereas primer ISSR 12 produced one monomorphic band and three polymorphic bands (75\% polymorphism). The mean percentage of polymorphism generated by four primers was $63.75 \%$. The size of the amplified fragments was ranged from 940 to 5148 bp for primers ISSR07, ISSR16 and ISSR21, and 1375 to 5148 bp for primer ISSR12. Although, level of polymorphism exhibited by different primers varied from intermediate $(60 \%)$ to high $(75 \%)$, all primers could distinguish parent and gamma irradiated mutant varieties of okra. Of the four primers tested, ISSR16 and ISSR21 were noticed to be superior over the other two primers in terms of clear and compact band patterns.

Polymorphisms generated by ISSR primers can be attributed to any of these reasons: i) a genome misses the repeated sequence; ii) distance between the repeats is altered by deletion or an insertion and/or iii) variations in the length of microsatellites [34]. In the present study, ISSR fingerprinting was effective in evaluating genetic variation in gamma ray induced okra mutants and the morphological changes in the studied mutants can be attributed to variations at a single locus or more than one loci [34].

Figure 2 shows the Neighbor-joining dendrogram developed using the UPGMA method formed two major clusters having two parents and two mutants each. In the upper cluster, parent varieties were grouped together indicating high genetic similarity but the mutant varieties did not show a well-defined grouping. In the lower cluster, both parent and mutant varieties were grouped separately.

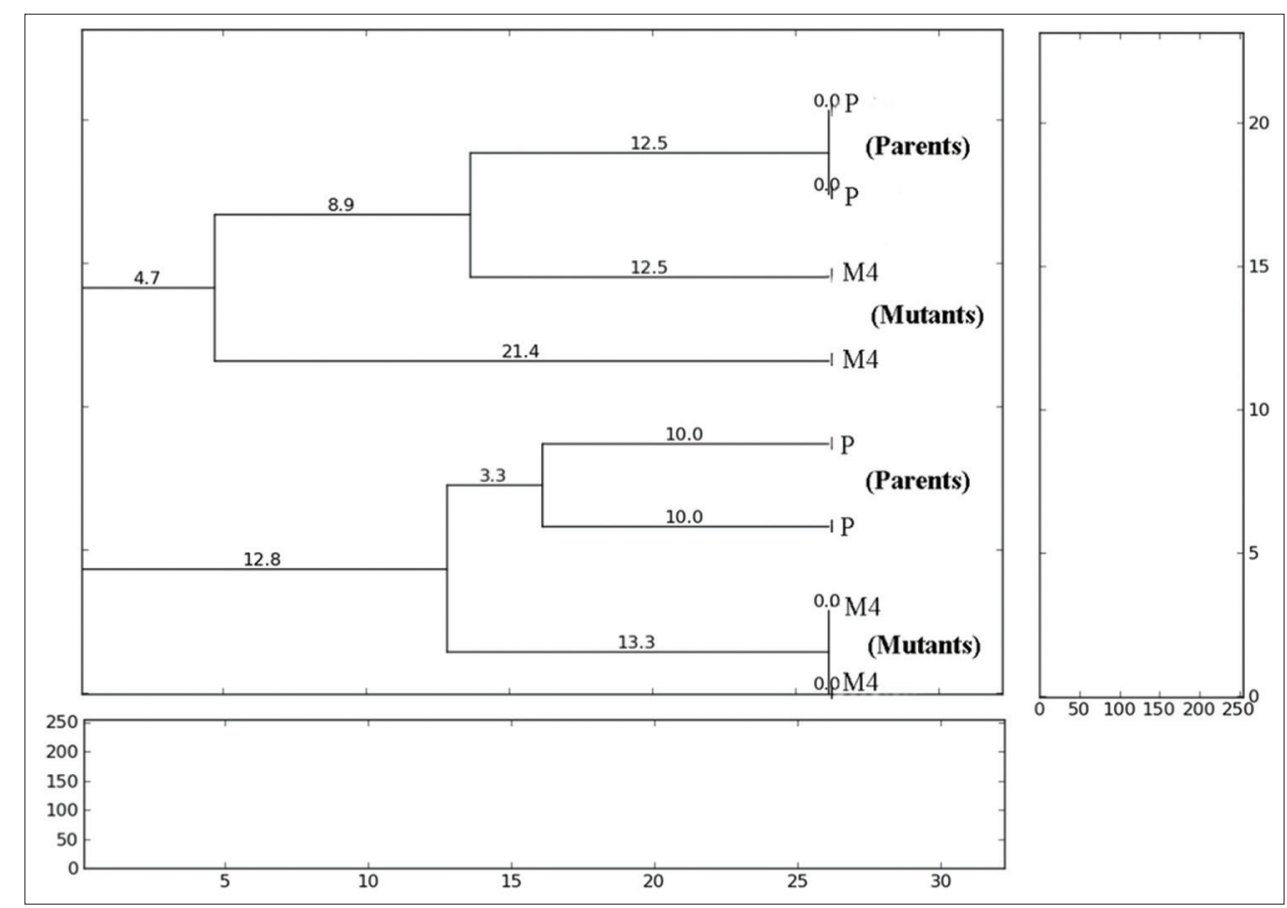

Figure 2: Neighbor-joining Dendrogram indicating relationships between Parent $(P)$ and Mutant $\left(M_{4}\right)$ 
Table 2: The detailed information regarding the selected ISSR primers and scoring

\begin{tabular}{|c|c|c|c|c|c|c|c|c|}
\hline \multirow[t]{2}{*}{ Locus } & \multicolumn{2}{|c|}{ ISSR07 } & \multicolumn{2}{|c|}{ ISSRI2 } & \multicolumn{2}{|c|}{ ISSRI6 } & \multicolumn{2}{|c|}{ ISSR21 } \\
\hline & $\mathrm{P}$ & $\mathrm{M}_{4}$ & $\mathrm{P}$ & $\mathrm{M}_{4}$ & $\mathrm{P}$ & $\mathrm{M}_{4}$ & $P$ & $M_{4}$ \\
\hline 1 & 0 & 1 & 0 & 1 & 1 & 0 & 1 & 0 \\
\hline 2 & 1 & 1 & 1 & 1 & 1 & 1 & 1 & 1 \\
\hline 3 & 1 & 1 & 0 & 0 & 0 & 0 & 0 & 0 \\
\hline 4 & 1 & 0 & 1 & 0 & 1 & 1 & 1 & 1 \\
\hline 5 & 0 & 0 & 0 & 1 & 0 & 0 & 0 & 0 \\
\hline 6 & 0 & 0 & 0 & 0 & 0 & 1 & 0 & 1 \\
\hline 7 & 0 & 1 & 0 & 0 & 1 & 0 & 1 & 0 \\
\hline 1 & 0 & 1 & 0 & 1 & 1 & 0 & 1 & 0 \\
\hline
\end{tabular}

The developed ISSR markers could discriminate parent and gamma irradiated mutant of okra. Out of 12 ISSR markers studied, ISSR07, ISSR12, ISSR16, and ISSR21 markers could find polymorphism and hence these markers can be utilized in promoting future population genetic studies and breeding programs for okra and related species as for obtaining adequate insights into the breeding history and genetic relationship of crop germplasm, knowledge on genetic variability is essential [22]. As the developed mutant showed resistance to yellow vein mosaic virus in field conditions by using disease scoring scale [33], identification of genetic variation between parent and mutant varieties is crucial to facilitate preservation strategies. Molecular marker-assisted selection of induced mutants helps to utilize the possibility of developing heterosis by crossing [34]. In maize mutants, heterosis was reported in the $\mathrm{Fl}$ generation [35].

\section{CONCLUSIONS}

The degree of genetic variability available within species is one of the most important determining factors in the successful genetic improvement of crop plants [36]. Mutant varieties of many crop plants have exhibited novel traits, increased yield and elevated resistance to various pathogens $[37,38]$. In this study, as the developed mutants revealed a high degree of genetic variability from parents, induced okra mutants are expected to be useful in the further induction of genetic variability for the enhancement of quantitative traits. Further, the present investigation can be extended to study the association between the genetic variation and subsequent changes in morphological traits using chromosome based SSR markers.

\section{ACKNOWLEDGEMENT}

The authors are thankful to Dr. Rahul R. Nair, Research Scientist, Centre for Evolutionary Ecology, Aushmath Biosciences, Vadavalli (P.O.), Coimbatore (Dist.), Tamil Nadu for helping the completion of the work.

\section{REFERENCES}

1. Arapitsas P. Identification and quantification of polyphenolic compounds from okra seeds and skins. Food Chem. 2008; 110:10411045.

2. Karakoltsidis PA, Constanfinidos SH. Okra seeds--A now protein source. J. Agric. Food Chem.1975; 23: 1204-I207.
3. Lengsfeld C, Titgemeyer F, Faller G, Hensel A. Glycosylated compounds from okra inhibit adhesion of Helicobacter pylori to human gastric mucosa. J. Agric. \& Food Chem. 2004; 52:1495-1503.

4. Al-Wandawi H. Chemical composition of seeds of two okra cultivars. J. Agric. Food Chem. 1983; 31: 1355-1358.

5. APEDA. Agro-export statistics. Agriculture and Processed Food Export Development Agency, New Delhi, India;2000.

6. Das S, Pandey V, Patel HR, Patel KI. Effect of weather parameters on pest-disease of okra during summer season in middle Gujarat. Journal of Agrometeorology. 2011;(13)1:38-42.

7. Pun KB, Doraiswamy S. Effect of age of okra plants on susceptibility to Okra yellow vein mosaic virus. Indian J. Virol. 1999; 15:57-58.

8. Jose S, Usha R. Bhendi yellow vein mosaic virus. In: Rao GP, Kumar PL and Holgun-Pena RJ. (eds). Characterization, Diagnosis and Management of Plant Viruses. Studium Press, Houston, Texas, USA. 2008; 3:387-392.

9. Pushparanjan G, Surendran S, Harinarayanan MK. Effect of gamma rays on yield attributing characters of okra [Abelmoschus esculentus (L.) Moench]. Inter.J.Adv.Res. 2014; (2) 5:535-540.

10. Lee YI, Lee IS, Lim YP. Variation in seed potato regenerates from gamma rays irradiated embryogenic callus. J. Plant Biotech. 2002; 4: 163-170

11. Chikelu Mba. Induced Mutations Unleash the Potentials of Plant Genetic Resources for Food and Agriculture. Agronomy, 2013; 3: $200-231$

12. Maluszynski M, Nichterlein, Vanzanten L, Ahloowalia B. Officially released mutant varieties - The FAO/IAEA database.MI: Itat.-8T.esd. Rev. 2000; 12:1-84.

13. Surendan S, Udayan PS. Gamma Rays Induced Mutations on Morphological and Yield Attributing Characters in $\mathrm{M}_{2}$ Generation of Okra [Abelmoschus esculentus (L.) Moench]. Int.J.Curr.Microbiol. App.Sci. 2017; 6: 3623-3628.

14. Manju P, Gopimony R. Anjitha- A new okra variety through induced mutation in interspecific hybrids of Abelmoshus Spp. Induced plant mutations in the genomics era. Food and agriculture organization of the United Nations, Rome. 2009; 87-90.

15. Phadvibulya V, Boonsirichai K, Adthalungrong A, Srithongchai W. Selection for resistance to Yellow Vein Mosaic Virus Disease of okra by induced mutation. Induced plant mutations in the genomics era. Food and agriculture organization of the United Nations, Rome. 2009; 349-351.

16. Hegazi $A Z$, Hamideldin $N$. The effect of gamma irradiation on enhancement of growth and seed yield of okra [Abelmoschus esculentus (L.) Monech] and associated molecular changes. J. Hortic. For. 2010; 2(3): 038-051.

17. Muralidharan G, Rajendran R. Effect of Gamma rays on germination, seedling vigour, survival and pollen viability in $\mathrm{M} 1$ and $\mathrm{M} 2$ generation of bhendi (Abelmoschus esculentus (L).) J. Environ Curr and Life Sci. 2013; 1: 41-45.

18. Elangovan R, Pavadai P. Effect of gamma rays on germination, morphological and yield characters of Bhendi (Abelmoschus esculentus (L.) Moench). Horticultural Biotechnology Research. 2015; 1: 35-38.

19. Paterson AH, Tanksley SD, Sorrells ME. DNA markers in plant improvement. Adv. Agron.1991; 46: 39-90.

20. Soller M, Beckmann JS. Genetic polymorphism in varietal identification and genetic improvement. Theor. Appl. Genet. 1983; 67: 25-33.

21. Xu F, Sun M. Comparative analysis of phylogenetic relationships of grain amaranths and their wild relatives (Amaranthus; Amaranthaceae) using internal transcribed spacer, amplified fragment length polymorphism, and double-primer fluorescent intersimple sequence repeat markers. Mol. Phylogenet. Evol. 2001; 21:372-387.

22. Štefú nová V, Bežo M. Genetic diversity analysis of amaranth (Amaranthus cruentus) germplasm collection by RAPD. Biol. 2003; 58:53-58.

23. Ray T, Roy SC. Genetic diversity of Amaranthus species from the Indo-Gangetic plains revealed by RAPD analysis leading to the development of ecotype-specific SCAR marker. Oxford J. 2008; 100:338-347

24. Popa G, Cornea CP, Ciuca M, Babeanu N, Popa O, Marin D. Studies on genetic diversity in Amaranthus species using the RAPD markers. Analele Universitati din Oradea - Fascicula Biol. Tom. 2010; 17: 280-285. 
25. Jafari SH, Sepehry A, Soltanloo H, Karimian AA. Genetic differentiation between bitter and sweet asafetida plants using ISSR markers. Molecular Biology Reports. 2019.

26. Sethy NK, Shokeen B, Edwards KJ, Bhatia S. Development of microsatellite markers and analysis of intraspecific genetic variability in chickpea (Cicer arietinum L.). Theor. Appl. Genet. 2006; 112: 14161428.

27. Yuan CY, Zhang C, Wang P, Hu S, Chang HP, Xiao WJ, Lu XT, Jiang SB, Ye JZ, Guo XH. Genetic diversity analysis of okra (Abelmoschus esculentus L.) by inter-simple sequence repeat (ISSR) markers. Genet. Mol. Res. 2014; (13) 2: 3165-3175.

28. Zietkiewicz E, Rafalski A, Labuda D. Genome fingerprinting by simple sequence repeat (SSR)-anchored polymerase chain reaction amplification. Genomics.1994; 20: 176-183.

29. Ajibade SR, Weeden NF, Chite SM. Inter simple sequence repeat analysis of genetic relationships in the genus Vigna. euphytica. 2000;111: 47-55.

30. Singh S, Reddy KS, Jawali N. PCR analysis of mungbean genotypes using anchored simple sequence repeat primers. In: DAE-BRNS symposium on the use of nuclear and molecular techniques in crop improvement, 6-8 December, BARC, Mumbai. 2000; 359-369.
31. Singh DR, Srivastava AK, Srivastava A, Srivastava RC. Genetic diversity among three Morinda species using RAPD and ISSR markers. Indian J. Biotechnol. 2011; 10:285-293.

32. Rodrigue L, Berg C, Povoa O, Monteiro A. Low genetic diversity and significant structuring in the endangered Mentha cervina populations and its implications for conservation. Biochem. Syst. Ecol. 2013; 50:51-61.

33. Arumugam R, Chelliah S, Muthu Krishnan CR. Abelmoschus manihot. A source of resistance to bhindi yellow vein mosaic. Madras Agri. J.1975; 62: 310-312

34. Souframanien J, Pawar SE, Rucha AG. Genetic variation in gamma ray induced mutants in blackgram as revealed by RAPD and ISSR markers. Indian J. Genet. 2002; (62) 4: 291-295.

35. Jones DF. Heterosis resulting from deg $\sim$ nerative changes. Genetics, 1945; 30: 527-542.

36. Singh P, Sharma H, Srivastava N, Bhagyawant S. Analysis of genetic diversity among wild and cultivated chickpea genotypes employing ISSR and RAPD markers. Am. J. Plant Sci. 2014; 5:676-682.

37. Ahloowalia BS, Maluszynski M, Nichterlein K. Global impact of mutation-derived varieties. Euphytica. 2004; 135: 187-204.

38. Sangsiri C, Sorajjapinun W, Srinives P. Gamma radiation induced mutations in mung bean. Science Asia. 2005; 31: 251-5. 